\title{
Evolution of Strategic Flexibility and Decision Making Process: A Conceptual Framework
}

\author{
Sunayana $^{1}$ and Rakhshanda Parveen ${ }^{2}$ \\ ${ }^{1}$ Assistant Professor, ${ }^{2}$ Research Scholar \\ ${ }^{1 \& 2}$ Centre for Management Studies, Jamia Millia Islamia, New Delhi, India \\ E-Mail: rakhshanda_93@outlook.com
}

\begin{abstract}
The dynamic nature of the environment in which a firm operates, demands a very adaptive and flexible decisionmaking process from the managerial point of view. There is a need to understand the elements of strategic flexibility and the process of efficient decision-making and implementation. Hence this paper reviews the literature and systematically analyses the results on the basis of different criteria. Various aspects of strategic flexibility were interpreted and linked through a conceptual framework. Scholarly database "Web of Science" has been scanned resulting in the inclusion of various qualitative, quantitative and empirical studies. The review consists of paper from various domain, i.e. services, exports, manufacturing, healthcare, etc., covering a period of 19752019. This study will help in better understanding of the evolution of the concept over time and will give a clear-cut step in the decision-making process. Finally, this paper will open several avenues for further studies providing a base for empirical researches.
\end{abstract}

Keywords: Decision-Making, Management Cognition, Strategic Options, Strategic Flexibility

\section{INTRODUCTION}

The current utopian corporate world has created an inescapable need for a continuous stream of feedback and therefore, a necessity to constantly upgrade the requirements of the business according to its environment and customers. The traditional strategic management has always dredged up the environmental threats and opportunities, their impact on the business and the necessary organizational responses to counter-act those forces. But, due to an upsurge in business uncertainties, like technological breakthroughs, intense competition, shortening product life cycles and globalization, it becomes very demanding for the managers to rely entirely on the conventional strategic management approaches. This created a need for other strategic options as well, and hence the paradigm of strategic flexibility came into the arena, which bridges the gaps of traditional strategic management in a contemporary way.

In simple terms, strategic flexibility can be defined as the ability to do something, other than the intended course of action, if a situation arises. Aaker and Mascarenhas (1984), state that strategic flexibility enables firms to manage under turbulent and uncertain environmental conditions by creating a flexible resource pool and various strategic options. Although the existing reviews are vast and comprehensive, there is a meagre of the literature that focuses on strategic flexibility itself (Brozovic, 2018). The question of how the flexibility is implemented and the problems are solved, is addressed by only a few of the subject-specific papers. Therefore, this study intends to first explore the literature on strategic flexibility based on their pattern, themes, and summarize the results accordingly. Next, it involves the development of a conceptual model based on various themes, extending the framework proposed by Combe, Rudd, Leeflang and Greenley (2012).

Consequently, the following research objectives have been developed

1. Systematically review the literature related to strategic flexibility.

2. Coherently scrutinize the literature related to the process of performing strategic flexibility by identifying its main characteristics and

3. Linking various aspects of strategic flexibility using a conceptual framework.

\section{METHODOLOGY}

For the purpose of this study, online database 'Web of Science' has been used. The core collection of this database has a vast and comprehensive multidisciplinary literature also focusing on management-related topics. The keywords "strategic flexibility", 'strategic flexibility process', 'strategic flexibility decision-making', etc. were searched. This resulted in a total of 2498 articles published from 1989 to 2019. 59 articles were in a language other than English, hence excluded. Some articles used flexibility and strategy in a general sense. Some authors further included market flexibility, supply chain flexibility and operational flexibility in their article. Hence, after the first round, the articles were reduced to 379 articles that used strategic flexibility as a single concept. During the next phase, the abstract of the articles was analysed. This resulted in the elimination of those articles which do not deal directly with strategic flexibility but have it in their keyword or the articles that dealt with similar concepts like dynamic capabilities, strategic agility. Some articles used different words like managerial flexibility, strategy adaptivity but proposed the same concept were included. The reference list of the articles scanned which resulted in the addition of 
some classic papers of the field dating prior to 1989 (Ansoff, 1975; Eppink, 1978; Aaker \& Mascarenhas, 1984). This left us with a final list of 110 articles which were used for the in-depth analysis. The process is presented in Fig. 1 below.
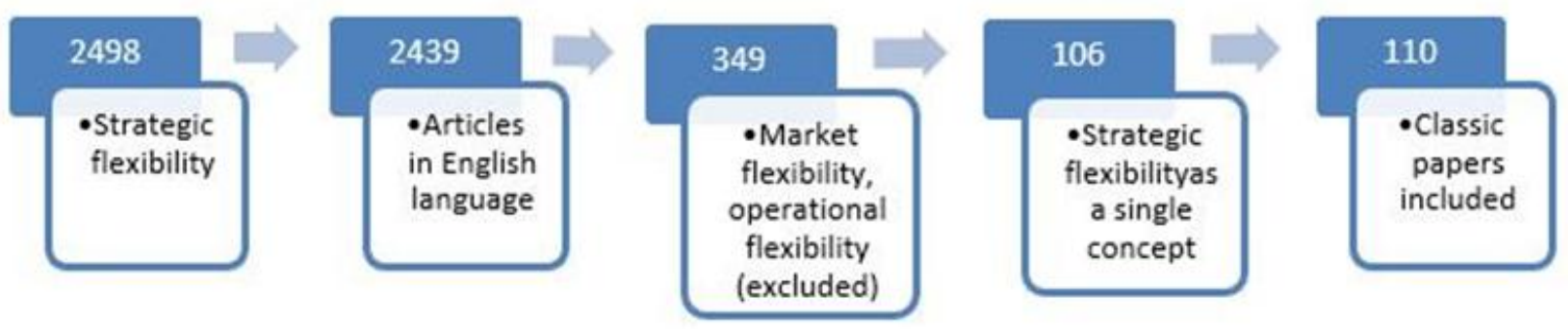

Fig. 1 Article Selection Processrs' analysis

\section{DESCRIPTIVE ANALYSIS}

A final list of 110 articles was identified and analysed systematically based on their year of publications, the industry domain, and various themes. The results of analysis are presented in the following sections.

\section{A. Year-wise classification}

The study presents the articles first published in 1975 and included articles until 2019. This is presented in Fig. 2 below. The upsurge in the publications has been increased considerably over time.

A Lower number of publications in 2019 is due to the fact that the articles only up to April 2019 were taken for the study. The year 1978-1990 has some classic papers building up the concept of strategic flexibility. Ansoff (1975) have used the concept at a very early stage and indicated it with the term 'response to strategic surprise' or 'response strategies'.

He has explained two types of flexibilities: internal and external, and proposed a structure for various alternatives. Aaker and Mascarenhas (1984) has further expanded this structure and presented approaches to achieve and increase flexibility. They have also provided ways to measure flexibility through objective and subjective assessments. On the other hand, Sanchez (1995) argued that flexibility in the product market is depended on resource flexibility and coordination flexibility.

While these articles described flexibility as a result of environmental changes, Das and Elango (1995) have proposed how flexibility can be used as a key to effective performance. They have laid down various internal and external factors to achieve the flexibility that will help improve corporate performance. Some models and frameworks are also formulated over time to understand the capabilities and factors that will lead to strategic flexibility (Combe \& Greenley, 2004).

Most of the earlier studies presented strategic flexibility as a reactive construct, responding to the situation and environment demands. On the other hand, the proactive construct has been realised lately (Sushil, 2015), dealing with the firms' ability to mould, shape and transform its environment (Brozovic, 2018). However, some earlier studies have also defined flexibility proactively as creating a new market (TenDam, 1987) and changing game plans (Harrigan, 1985), but they were less dominant.

A remarkable ascend in the literature can be seen since 2010, when models and frameworks were developed conceptually to understand the whole process of developing and implementing flexibility by managers through various strategic options (Combe et al., 2012). More recently, the studies are focused on how strategic flexibility can lead to innovation through dynamic capabilities (Liao, Liu, Fu \& Ye, 2019; Bamel \& Bamel, 2018; Li, Li, Wand \& Ma, 2017).

\section{Year of Publication}

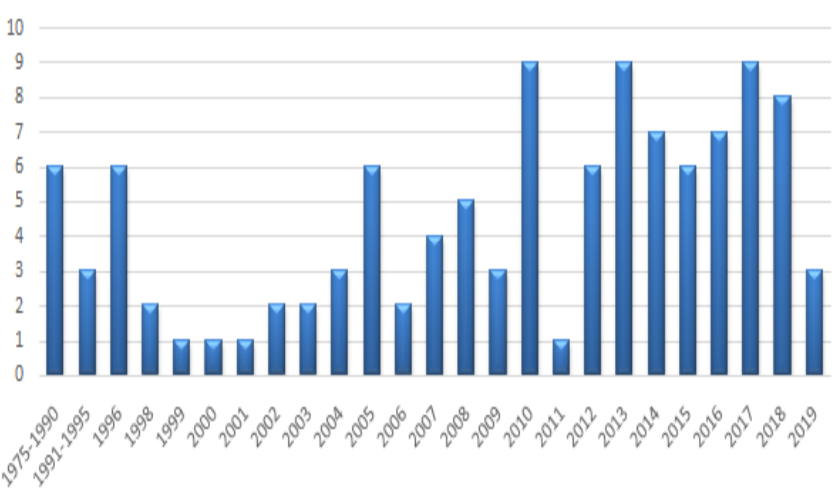

Source: Authors' analysis

Fig. 2 Articles based on Year of Publication

\section{B. Industry-wise classification}

As mentioned earlier, strategic flexibility has its prevalence in almost every industry sphere. This is reflected in the results of industry-wise classification given in Table I.

Through the assessment of the resulting articles, we found out that the studies encompassed a multiple array of industry. Most of the researches were carried out in the firms from various industry (Li et al., 2017; Zhang, 2005). The studies were also carried out in IT (Evans, 1991; Dai et 
al., 2018), healthcare (Bearly \& Chakrabarti, 1996), aviation (Claussen, 2018), banking (Roy, 2016) and manufacturing sectors (Ismail et al., 2015; Worren et al., 2002). This analysis shows that strategic flexibility is used across the industries, irrespective of their size, type, and environment. It surely has emerged as a crucial requirement to thrive in a complex business environment (Hamlin et al., 2012). The analysis also included various review papers encompassing different context of the area (Brozovic, 2018; Kortmann, Gelhard, Zimmermann \& Piller, 2014, Combe, 2012). The industry-wise results are presented through the treemap in Fig. 3.

TABLE I ARTICLES BASED ON TYPES OF INDUSTRY

\begin{tabular}{|c|c|}
\hline $\begin{array}{l}\text { Types of } \\
\text { industry }\end{array}$ & Articles \\
\hline IT & $\begin{array}{l}\text { Evans, 1991; Young-Ybarra, 1999; Raynor and Leroux, 2004; Rajala, Westerlund \& Moller, 2012; Li, Zhou, } \\
\text { Zhang, Chen \& Tian, 2018; Dai, Goodale, Byun \& Ding, 2018; Liao et al., } 2019\end{array}$ \\
\hline Healthcare & Goodstein, Boeker\& Stephan, 1996; Bierly and Chakrabarti, 1996, Ginn and Lee, 2006 \\
\hline SMEs & $\begin{array}{l}\text { Grewal and Tansuhaj, 2001; Zahra,Hayton, Neubaum, Dibrell \& Craig, 2008; Fernández-Pérez, Montes \& } \\
\text { Garcìa-Morales, 2014; Guo and Cao, 2014; Bamel and Bamel, } 2018\end{array}$ \\
\hline Manufacturing & $\begin{array}{l}\text { Price, Beach, Muhlemann,Sharp \& Paterson, 1998; Beach, Muhleman \& Price, 2000; Worren, Moore \& } \\
\text { Cardona, 2002; de Weerd-Nederhof, Visscher, Altena\&Fisscher, 2008; Tamayo-Torres, Ruiz-Moreno \& Verdu, } \\
\text { 2010; Fan, Wu \& Wu, 2013; Singh, Oberoi \& Ahuja, 2013; Ismail, Razak \& Lazim, 2015; Chen, Wang, Nevo, } \\
\text { Benitez \& Kou, 2017; Schulze and Heidenreich, } 2017\end{array}$ \\
\hline Services & $\begin{array}{l}\text { Krupp and Davidson, 1996; Roca-Puig,Beltran-Martın, Escrig-Tena \& BouLlusar, 2005; Nadkarni and } \\
\text { Herrmann, 2010; Gylling, Elliott \& Toivonen, 2012; Arnold, Benford, Canada, \& Sutton, 2015; Perez- } \\
\text { Valls,Cespedes-Lorente \& Moreno-Garcia, 2016; Roy, 2016; Yawson and Greiman, 2017; Claussen, } \\
\text { Essling\&Peukert, 2018; Choi, Ju,Kotabe, Trigeorgis \& Zhang, } 2018\end{array}$ \\
\hline Multiple & $\begin{array}{l}\text { Zhang, 2005; Gomez-Gras and Verdu-Jover, 2005; Cabello-Medina, Carmona-Lavado \& Valle-Cabrera, 2006; } \\
\text { Nadkarni and Narayanan, 2007; Verdú-Jover, Gómez-Gras \& Lloréns-Montes, 2008; Tan and Zeng, 2009; } \\
\text { Verdu and Gómez-Gras, 2009; Li, Su\& Liu, 2010; Gutiérrez-Gutiérrez and Fernández-Pérez, 2010; Fernandez- } \\
\text { Perez et al., 2014; Bock, Opsahl, George \& Gann, 2012; Liu, Jiang, Zhang \& Zhang, 2013; Kortmann, 2014; } \\
\text { Wei, Yi \& Guo, 2014; Ouakouak and Ammar, 2015; Wang, Libaers \& Jiao, 2015; Kamasak, Yozgat \& Yavuz, } \\
\text { 2017; Li et al., 2017; Gong, 2017, Yi, Gu\& Wei, 2017; Xiu, Liang, Chen \& Xu, 2017; Anwar and Hasnu, 2017; } \\
\text { Wang, Qi \& Zhou, } 2018\end{array}$ \\
\hline Export & $\begin{array}{l}\text { Pauwels and Matthyessen, 2004; Lagoudis, Naim\& Potter, 2010; Lin and Chen, 2009; Mason and Nair, 2013; } \\
\text { Ying, Deng \& Liu, 2016; Shadi, } 2016\end{array}$ \\
\hline University & Evans, Kirby \&Fabrigar, 2003; Xu, Wells, LeFevre \&Imbo, 2014 \\
\hline Hotel & Dwyer, Cvelbar, Edwards \&Mihalic, 2014; de Soto-Camacho and Vargas-Sanchez, 2015 \\
\hline
\end{tabular}

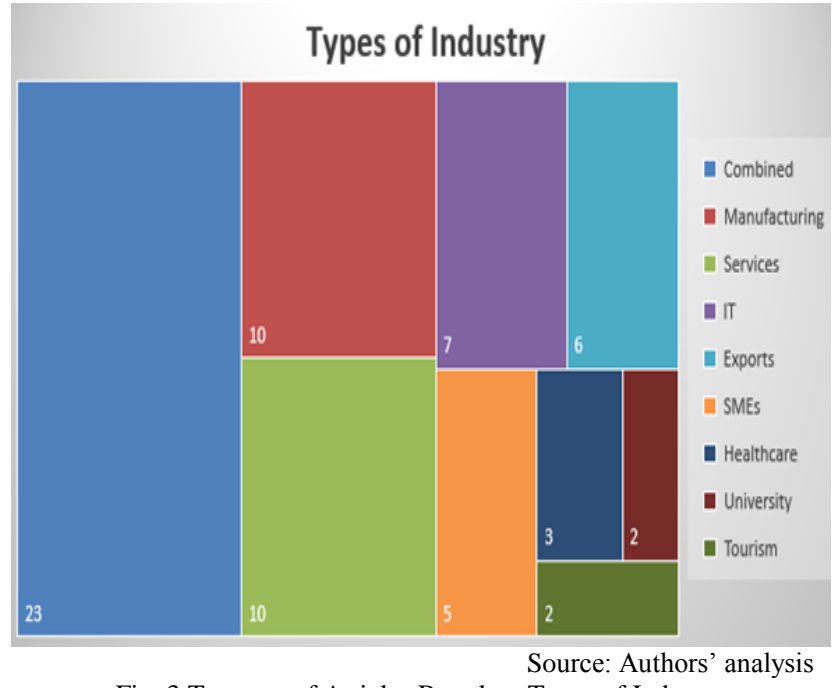

Fig. 3 Treemap of Articles Based on Types of Industry

\section{DEVELOPMENT OF THE CONCEPTUAL MODEL}

The next step in the literature review is to develop a framework that will create a conceptual understanding of the concept.
The review extended the framework proposed by Combe $e t$ al., (2012) and identified various elements. These elements have been classified in Table II.

The process is categorized into four main elements.

1. Management cognition

2. Identifying and evaluating the environment

3. Development of strategic options and outcomes

The relationship between these elements is shown in Fig. 4.

The figure presupposes that the identification of changes in the environment and evaluating the potential changes based on their size and impact requires management cognition from decision-makers in the form of strategic schemas, information processing, cognitive content, etc.

This leads to the development of various strategic options through careful scrutiny of the competitive situation.

By choosing the best strategic option, flexible behaviour can be incorporated through resource and coordination flexibility and the favourable outcomes can be achieved. The next section of this review will discuss each element elaborately. 
TABLE II ARTICLES B ASED ON THEME

\begin{tabular}{|c|c|}
\hline Elements & Articles \\
\hline \multicolumn{2}{|r|}{ Management Cognition } \\
\hline Cognitive content & $\begin{array}{l}\text { Evans et al. 2003; Combe and Greenley, 2004; Fernandez-Perez, Garcìa- } \\
\text { Morales \& Pulles } 2016\end{array}$ \\
\hline Strategic schemas & Fisk and Taylor, 1991; Nadkarni and Narayanan, 2007 \\
\hline Information processing & $\begin{array}{l}\text { Lord and Foti, 1986; Fisk and Taylor, 1991; Sharfman and Dean, 1997; } \\
\text { Zhang, } 2005\end{array}$ \\
\hline Management learning & Bierly and Chakrabarti, 1996; Evans et al., 2003; Saini and Johnson, 2005 \\
\hline Knowledge & Fernández-Pérez et al., 2014; Arnold et al., 2015 \\
\hline \multicolumn{2}{|r|}{ Environmental Factors } \\
\hline Identification and evaluation of factors & $\begin{array}{l}\text { Eppink, 1978; Aaker and Mascarenhas, 1984; Grewal and Tansuhaj, 2001; } \\
\text { Shimizu and Hitt, 2004; Fan et al., 2013; Fernández-Pérez and Gutiérrez, } \\
\text { 2013; Kurt and Hulland, } 2013\end{array}$ \\
\hline \multicolumn{2}{|r|}{ Development of Strategic Options } \\
\hline Competitive factors, competence building & $\begin{array}{l}\text { Das and Elango, 1995; Zhang, 2005; Rudd, Greenley, Beatson \& Lings, } \\
\text { 2008; Tan and Zeng, 2009; Fernández-Pérez et al., 2016; Combe, 2012, } \\
\text { Roh, Yang, Park \& Hong, } 2015\end{array}$ \\
\hline Flexible behaviour/ Strategic Flexibility & Grewal and Tansuhaj, 2001; Shimizu and Hitt, 2004 \\
\hline \multicolumn{2}{|r|}{ Outcomes } \\
\hline Competitive advantage & $\begin{array}{l}\text { Fiegenbaum and Karnani, 1991; Hitt, Keats \& DeMarie, 1998; Dreyer and } \\
\text { Grønhaug, 2004; Rindova and Kotha, 2001; Reddy, 2006; Nandakumar, } \\
\text { Jharkharia \& Nair, } 2014\end{array}$ \\
\hline New product development & $\begin{array}{l}\text { Das and Elango, 1995; Bierly and Chakrabarti, 1996; Kandemir and Acur, } \\
\text { 2012; Wei et al., } 2014\end{array}$ \\
\hline Innovation & $\begin{array}{l}\text { Li et al., 2017, Zhou and Wu, 2010; Rajala et al., 2012; Arief, Thoyib, } \\
\text { Sudiro, \& Rohman, 2013; Kamasak et al., 2017; Liao } \text { et al., } 2019\end{array}$ \\
\hline Operational/ financial performance & $\begin{array}{l}\text { Abbott and Banerji, 2003; Guo and Cao, 2014; Kortmann, Gelhard, } \\
\text { Zimmermann\&Piller, 2014; Shadi, } 2016\end{array}$ \\
\hline Expansion/ New market entry & $\begin{array}{l}\text { Liu et al., 2013; de Soto-Camacho\&Vargas-Sanchez, 2015; Ying et al., } \\
\text { 2016; Claussen et al., 2018; Choi et al., 2018; }\end{array}$ \\
\hline
\end{tabular}

Source: Authors' analysis

\section{A. Management Cognition}

Strategic flexibility can be employed both at the firm level and the decisionmaker level (Evans, 1991; Fiegenbaum \& Karnani, 1991). In order to incorporate strategic flexibility at firm's level, capabilities and cognition are required from the part of the decision makers, which bring us to the fact that generating strategic flexibility and taking decisions regarding it, is different for different managers. The probable reason as explained by Combe and Greenley (2004) may be the contrasting beliefs in cognitive model content that influence decision makers' capabilities to create different types and forms of strategic flexibility. Management cognition is also presented in the form of strategic schemas (Nadkarni \& Narayanan 2007). It is described as a knowledge map or structure which helps the top managers in decision making. One important point that is highlighted out is, in scanning and data processing, several participants may be involved but the ultimate decision-making, and the actions thereof are in the hands of the top managers. Hence, strategic schemas are believed to influence the identification of change as well as actions that lead to strategic flexibility and subsequently flexible behaviour. Some authors have argued that management cognition is also represented by tacit knowledge, management learning and information processing (Saini \& Johnson, 2005; Sharfman \& Dean, 1997)

\section{B. Identifying Environmental Changes and Evaluating Potential Changes}

An organization may face changes and uncertainties in both its internal and external environment. The extent of change varies from firm to firm because they operate in a dynamic environment. Moreover, the source of these changes may also vary and may include competition, technological upgradation, suppliers, etc. After the source of change is identified, the next step is to evaluate each change on the basis of their nature, size, impact, and likelihood to the organization. This will help to reduce the environmental changes to a manageable number and if not, it will at least help to prioritize those changes (Aaker \& Mascarenhas, 1984). The top manager's decision regarding the above will help the firm to focus on the potential changes and to be prepared to cope up with the uncertainties.

\section{Development of Strategic Options}

Strategic options can be created through the development of an alternative course of action. Once the potential changes 
are identified, it is important to develop strategic options for each screened out change. It also includes identifying the areas- finance, marketing, operation, etc- in which the adaptation is likely to take place. Cost-benefit analysis can also be used to evaluate the flexibility option and find out the resource requirement (Aaker \& Mascarenhas, 1984). Sanchez \& Heene(1997) in their paper focused on competence building as a strategic option. To meet the demand for the uncertain future, the firms must develop new competencies as a strategic option. Meanwhile, it should also utilise its existing competencies to respond to the current opportunities and threats faced by the firm. Just like environmental screening, development of strategic options is a result of management cognition.

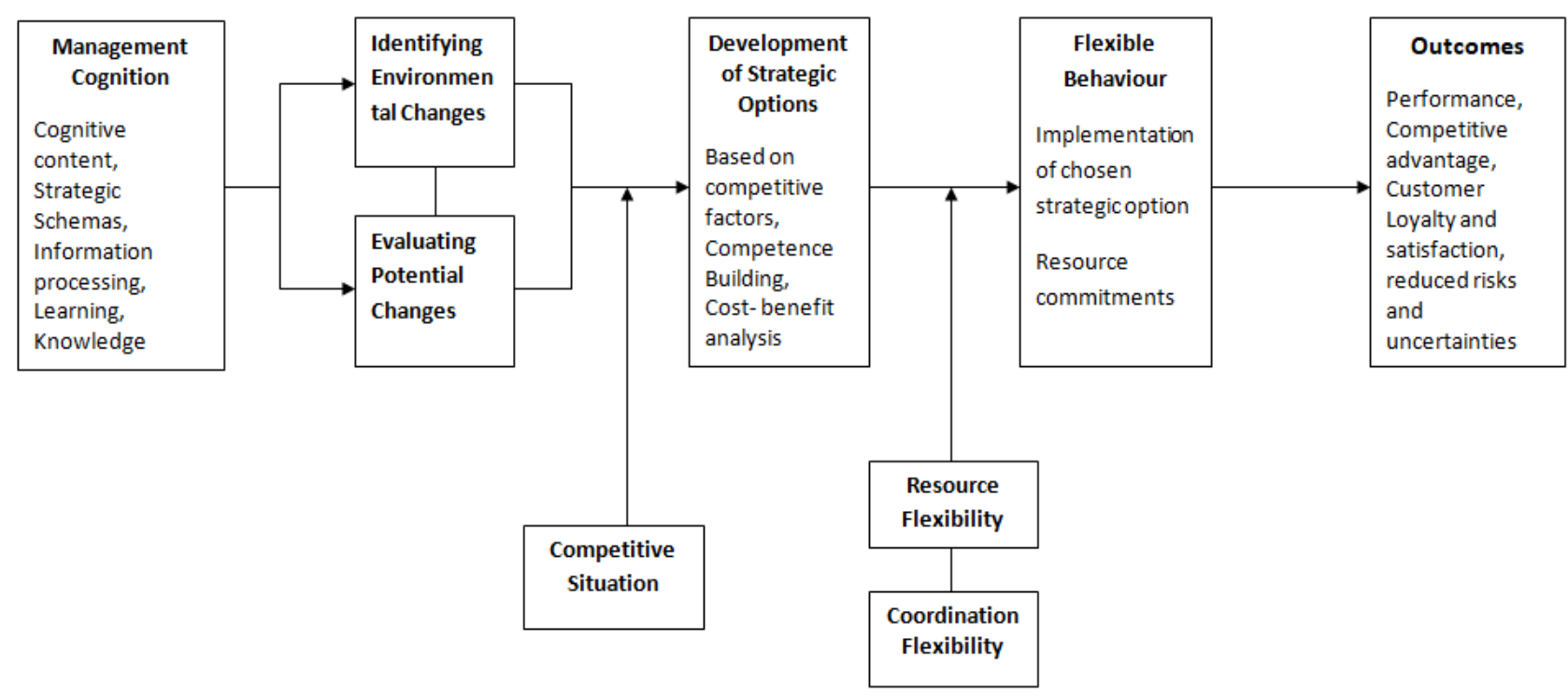

Fig. 4 Strategic Flexibility Decision-Making and Implementation Process

\section{Flexible Behaviour}

Once the best strategic option has been chosen, the next step is to implement and incorporate it. The implementation is greatly influenced by resource and coordination flexibilities as shown in Figure 4. Due to flexibility in resources, they can be put to alternative uses and the coordination among them will make the process faster and efficient. Merely development of strategic options is not enough and even the adoption of an option is not enough, until and unless the managers recognize the need to halt and reverse the resource commitments. This can be overcome by measuring and monitoring decision outcomes, creating a dynamic mechanism and decision portfolios and analysing and measuring learning (Shimizu \& Hitt, 2004).

\section{E. Outcomes}

After the successful implementation of a favoured strategic option, the next step is to identify its effect on the firm. Strategic flexibility involves responding to the environment quickly and thereby creating or maintaining a competitive advantage (Hitt et al., 1998). Competitive advantage will create a position where it is difficult for the competitors to imitate the strategic options, but as the environment is dynamic, it is very important to sustain competitive advantage through continuous adaptations (Rindova \& Kotha, 2001). Competitive differentiation leads to customer satisfaction and loyalty and finally improved business performance (Combe et al., 2012). When considering the proactive side of strategic flexibility, the possible outcomes are: exploration and realization of new market and new product development (Das \& Elango, 1995, Kandemir \& Acur, 2012), increased innovation capabilities and a positive influence on entrepreneurial orientation (Arief et al., 2013).

\section{F. Competitive Situation}

The new competitive landscape has created extreme emphasis on price, quality, innovation and, focus on customers' needs. The time frame of strategic actions is also reduced. The current market has created blurring boundaries of business making it more difficult to identify the competitors. So, as argued by Combe et al. (2012), the competitive situation has a significant impact on the development and choice of different strategic options. It may also lead to the implementation of a different strategic option or the combination of various options.

\section{G. Resource Flexibility and Coordination Flexibility}

Once a strategic option has been chosen, the next step is to implement it effectively. The implementation involves that the organization has access to flexible resources so that it can be effectively coordinated and put to various alternative uses. Resource flexibility is greater when the resource can be put to a large number of alternative uses and when the switching costs of the resource are lower. It can also be 
increased by lowering the time required to switch to the alternative course of action. Coordination flexibility implies identifying and structuring the chains of resources that can be employed in the organization. It also helps to deploy the resources through organizational system and process that apply the available resources to the targeted use (Sanchez, 1997).

\section{DISCUSSION AND CONCLUSION}

Globalization, technological advancement, changing customer's preferences and deregulation of the market are some of the major challenges that an organization faces in its environment. This compels an efficient and proactive organization in the development of flexibility in resources, structure and decision-making, enabling the organization to adapt and adjust to the turbulent environment.

This paper has highlighted the fundamental steps that can be followed to achieve strategic flexibility. The basic elements of the concept have been identified and linked through a conceptual framework, developed through meta-review and presented in a more synthesized and refined manner. One of the building blocks of the framework presented was management cognition which includes strategic schemas, knowledge, learning, etc of the decision maker. It acts as a pre-requisite to identify the environmental changes and uncertainties and to effectively evaluate the potential change. Appropriate environmental scanning focusing on the potential change and to prepare the organization for coping up with the change is the best option. Because such changes cannot be avoided and if adaptation is inherited properly, it can lead to competitive advantage.

The framework presents a complex relationship between different steps in the implementation process, and various other progressions other than that mentioned in the model may exist. Apart from this, other moderating effects may also be present which can be identified when the model is used empirically. Management cognition is identified as the focal block in the strategic flexibility process, but factors like the extent of authority in the hands of the decision makers can also influence the implementation process. Likewise, pressure from different political and societal groups can also affect the decision making of the top managers. Building competencies and leverages can also act as a moderating effect in the development of strategic options (Sanchez, 1997).

One important aspect as mentioned by Shimizu and Hitt (2004) is that strategic flexibility also includes halting and reversing the resources once the need for the same is recognized. This can be a major implication to the above model. The framework can be further extended to recognize the time when the resource commitment to a particular action needs to be stopped and the flexibility decision needs to be reverted after the environment has been returned to the state of static. When applying the model empirically, alterations could be made according to the requirement and direction of the research. The empirical researches, specifically on the flexibility process are limited. Empirical researches may lead to more concrete steps in the implementation process. To conclude, it can be said that there are always avenues in an area of research. One string leads to several other strings. Further researches will add up to the knowledge of the academicians and intended industry people that will help to smoothly incorporate the strategic flexibility process.

\section{REFERENCES}

[1] Aaker, D. A., \& Mascarenhas, B. (1984). The need for strategic flexibility. Journal of Business Strategy, 5, 74-82.

[2] Abbott, A., \& Banerji, K. (2003). Strategic flexibility and firm performance: the case of US based transnational corporations. Global Journal of Flexible Management Systems, 4, 1-8.

[3] Ansoff, H. I. (1975). Managing strategic surprise by response to weak signals. California Management Review, 18(2), 21-33.

[4] Anwar, J., \& Hasnu, S.A.F. (2017). Strategic patterns and firm performance: comparing consistent, flexible and reactor strategies. Journal of Organizational Change Management, 30(7), 1015-1029.

[5] Arief, M., Thoyib, A., Sudiro, A., \&Rohman, F. (2013). The effect of entrepreneurial orientation on the firm performance through strategic flexibility: A study on the SMEs cluster in Malang. Journal of Management Research, 5, 44-62.

[6] Arnold, V., Benford, T., Canada, J., \& Sutton, S.J. (2015). Leveraging integrated information systems to enhance strategic flexibility and performance: The enabling role of enterprise risk management. International Journal of Accounting Information Systems, 19, 1-16

[7] Bamel, U. K., \& Bamel, N. (2018). Organizational resources, KM process capability and strategic flexibility: a dynamic resourcecapability perspective. Journal of Knowledge Management, 22(7), 1555-1572.

[8] Beach, R., Muhlemann, A.P., \& Price, D.H.R. (2000). Manufacturing operations and strategic flexibility: survey and cases. International Journal of Operations and Production Management, 20(1), 7-30.

[9] Bierly, P. E., \& Chakrabarti, A. K. (1996). Technological learning, strategic flexibility, and new product development in the pharmaceutical Industry. IEEE Transactions on Engineering Management, $43,368-380$.

[10] Bock, A. J., Opsahl, T., George, G., \& Gann, D. M. (2012). The effects of culture and structure on strategic flexibility during Business model Innovation. Journal of management studies, 49(2), 279-305.

[11] Brozovic, D. (2018). Strategic flexibility: A review of the literature. International Journal of Management Reviews, 20, 3-31.

[12] Cabello-Medina, C., Carmona-Lavado, A., \& Valle-Cabrera, R. (2006). Identifying the variables associated with types of innovation, radical or incremental: strategic flexibility, organisation and context. International Journal of Technology Management, 35(1-4), 80-106.

[13] Chen, Y., Wang, Y., Nevo, S., Benitez, J., \& Kou, G. (2017). Improving strategic flexibility with information technologies: insights for firm performance in an emerging economy. Journal of Information Technology, 32(1), 10-25

[14] Choi, J. J., Ju, M., Kotabe, M., Trigeorgis, L., \& Zhang, X. T. (2018). Flexibility as firm value driver: Evidence from offshore outsourcing. Global strategy Journal, 8(2), 351-376

[15] Combe, I. A. (2012). Marketing and flexibility: Debates past, present and future. European Journal of Marketing, 46, 1257-1267.

[16] Combe, I. A., \& Greenley, G. E. (2004). Capabilities for strategic flexibility: a cognitive content framework. European Journal of Marketing, 38, 1456-1480.

[17] Combe, I. A., Rudd, J. M., Leeflang, P. S. H., \&Greenley, G. E. (2012). Antecedents to strategic flexibility: management cognition, firm resources and strategic options. European Journal of Marketing, 46,1320-1339.

[18] Claussen, J., Essling, C., \& Peukert, C. (2018). Demand variation, strategic flexibility and market entry: Evidence from the US airline industry. Strategic Management Journal, 39(11), 2877-2898. 
[19] Dai, Y., Goodale, J., Byun, G., \& Ding, F. (2018). Strategic Flexibility in New High-Technology Ventures. Journal of Management Studies, 55(2), 265-294.

[20] Das, T. K., \& Elango, B. (1995). Managing strategic flexibility: key to effective performance. Journal of General Management, 20, 6075 .

[21] de Soto-Camacho, E. G., \& Vargas-Sanchez, A. (2015). Choice of entry mode, strategic flexibility and performance of international strategy in hotel chains: an approach based on real options. European Journal of Tourism Research, 9, 92-114

[22] De Weerd-Nederhof, P. C., Visscher, K., Altena, J., \&Fisscher, O. A. M. (2008). Operational effectiveness and strategic flexibility: scales for performance assessment of new product development systems. International Journal of Technology Management, 44(3-4), 354-372

[23] Dreyer, B., \& Grønhaug, K. (2004). Uncertainty, flexibility, and sustained competitive advantage. Journal of Business Research, 57, 484-494.

[24] Dwyer, L. M., Cvelbar, L. K., Edwards, D. J., \& Mihalic, T. A. (2014). Tourism firms' strategic flexibility: the case of Slovenia. International Journal of Tourism Research, 16, 377-387.

[25] Eppink, D. J. (1978). Planning for strategic flexibility. Long Range Planning, 11, 9-15

[26] Evans, C. J., Kirby, J. R., \& Fabrigar, L. R. (2003). Approaches to learning, need for cognition, and strategic flexibility among university students. British Journal of Educational Psychology, 73, 507-528.

[27] Evans, J.S. (1991). Strategic flexibility for high technology manoeuvres: a conceptual framework. Journal of Management Studies, 28, 69-89.

[28] Fan, Z., Wu, D., \& Wu, X. (2013). Proactive and reactive strategic flexibility in coping with environmental change in innovation. Asian Journal of Technology Innovation, 21, 187-201.

[29] Fernández-Pérez V., Garcìa-Morales, V. J., \& Pulles, D. C. (2016). Entrepreneurial decision-making, external social networks and strategic flexibility: The role of CEOs' cognition. European Management Journal, 34(3), 296-309

[30] Fernández-Pérez V., \& Gutiérrez, L. G. (2013). External managerial networks, strategic flexibility and organisational learning: a comparative study among non-QM, ISO and TQM firms. Total Quality Management and Business Excellence, 24, 243-258.

[31] Fernández-Pérez, V., Montes, F. J. L., \&Garcìa-Morales, V. J. (2014). Towards strategic flexibility: social networks, climate and uncertainty. Industrial Management and Data Systems, 114, 858-871.

[32] Fiegenbaum, A., \& Karnani, A. (1991). Output flexibility - a competitive advantage for small firms. Strategic Management Journal, 12, 101-114.

[33] Fisk, S. T., \& Taylor, S. E. (1991). Social Cognition (International Edition), McGraw-Hill.

[34] Ginn, G. O., \& Lee, R. P. (2006). Community orientation, strategic flexibility, and financial performance in hospitals. Journal of healthcare management, 51(2), 111-121.

[35] Gomez-Gras, J. M., \& Verdu-Jover, A. (2005). TQM, structural and strategic flexibility and performance: an empirical research study. Total Quality Management, 16, 841-860.

[36] Gong, H. (2017). The Relationship between strategy flexibility and innovation performance of enterprise in dynamic environment. Agro Food Industry Hi-Tech, 28(3), 427-431.

[37] Goodstein, J., Boeker, W., \& Stephan, J. (1996). Professional interests and strategic flexibility: a political perspective on organizational contracting. Strategic Management Journal, 17, 577586.

[38] Grewal, R., \& Tansuhaj, P. (2001). Building organizational capabilities for managing economic crises: the role of market orientation and strategic flexibility. Journal of Marketing, 65, 67-80.

[39] Guo, H., \& Cao, Z. (2014). Strategic flexibility and SME performance in an emerging economy: a contingency perspective. Journal of Organizational Change Management, 27, 273-298.

[40] Gylling, C., Elliott, R., \& Toivonen, M. (2012). Co-creation of meaning as a prerequisite for market-focused strategic flexibility. European Journal of Marketing, 46, 1283-1301.

[41] Gutiérrez-Gutiérrez, L. J., \& Fernández-Pérez, V. (2010). Managerial networks and strategic flexibility: a $\mathrm{QM}$ perspective. Industrial Management and Data Systems, 110, 1192-1214
[42] Hamlin, R., Henry, J., \& Cuthbert, R. (2012). Acquiring market flexibility via niche portfolios: the case of Fisher and Paykel Appliance Holdings Ltd. European Journal of Marketing, 46, 13021319.

[43] Harrigan, K. R. (1985). Strategic Flexibility. A Management Guide for Changing Times. Lexington, MA: Lexington Books.

[44] Hitt, M., Keats, B., \& DeMarie, S. (1998). Navigating in the new competitive landscape: Building strategic flexibility and competitive advantage in the 21 st century. Academy of Management Executive, 12(4), 22-43.

[45] Ismail, R. M., Razak, R. C., \& Lazim, H. M. (2015). Mediating impact of manufacturing technology, lean and strategic flexibility on manufacturing performance. JurnalTeknologi. 77(4), 77-90.

[46] Kamasak, R., Yozgat, U., \& Yavuz, M. (2017). Knowledge process capabilities and innovation: testing the moderating effects of environmental dynamism and strategic flexibility, Knowledge Management Research and Practice, 15(3), 356-368.

[47] Kandemir, D., \&Acur, N. (2012). Examining proactive strategic decision-making flexibility in new product development. Journal of Product Innovation Management, 29, 608-622.

[48] Kortmann, S. (2014). The mediating role of strategic orientations on the relationship between ambidexterity-oriented decisions and innovative ambidexterity. Journal of Product Innovation Management, 32, 666-684.

[49] Kortmann, S., Gelhard, C., Zimmermann, C., \& Piller, F. T. (2014). Linking strategic flexibility and operational efficiency: the mediating role of ambidextrous operational capabilities. Journal of Operations Management, 32, 475-490.

[50] Krupp, C., \& Davidson, C. (1996). Strategic flexibility and exchange rate uncertainty. Canadian Journal of Economics-Revue Canadienne D Economique, 29 (2), 436-456

[51] Kurt, D., \& Hulland, J. (2013). Aggressive marketing strategy following equity offerings and firm value: the role of relative strategic flexibility. Journal of Marketing, 77, 57-74

[52] Lagoudis, I. N., Naim, M. M., \& Potter, A. T. (2010). Strategic flexibility choices in the ocean transportation industry. International Journal of Shipping and Transport Logistics, 2(2), 187-205,

[53] Li, J. Zhou, L., Zhang, F., Chen, Z., \& Tian, F. (2018). Technological configuration capability, strategic flexibility, and organizational performance in Chinese high-tech organizations. Sustainability, 10(5), 1665.

[54] Li, Y., Li, P., Wang, H., \& Ma, Y. (2017). How do resource structuring and strategic flexibility interact to shape radical innovation? Journal of Product Innovation Management, 34(4), 471491.

[55] Li, Y., Su, Z., \& Liu, Y. (2010). Can strategic flexibility help firms profit from product innovation? Technovation, 30, 300-309.

[56] Liao, S., Liu, Z., Fu, L., \& Ye, P. (2019). Investigate the role of distributed leadership and strategic flexibility in fostering business model innovation. Chinese Management Studies, 3(1), 93-112.

[57] Lin, C-T., \& Chen Y. M. (2009). Hedging strategic flexibility in the distribution optimization problem. Omega- International Journal of Management Science, 37(4), 826-837.

[58] Liu, H., Jiang, X., Zhang, J. Q., \& Zhang, X. L. (2013). Strategic flexibility and international venturing by emerging market firms: the moderating effects of institutional and relational factors. Journal of International Marketing, 21(2), 79-98.

[59] Lord, R. G., \&Foti, R. J. (1986). Schema theories, information processing, and organizational behaviour, In Sims, H. P. Gioia, D. A. and Ass. (eds.), The Thinking Organization. Jossey- Bass, 20-48.

[60] Mason, R., \& Nair, R. (2013). Strategic flexibility capabilities in the container liner shipping sector. Production Planning \& Control, 24(7), 640-651.

[61] Nadkarni, S., \& Herrmann, P. (2010). CEO personality, strategic flexibility, and firm performance: the case of the Indian business process outsourcing industry. The Academy of Management Journal, 53(5), 1050-1073.

[62] Nadkarni, S., \& Narayanan, V. K. (2007). Strategic schemas, strategic flexibility, and firm performance: the moderating role of industry clock speed. Strategic Management Journal, 28, 243-270.

[63] Nandakumar, M. K., Jharkharia, S., \& Nair, A. S. (2014). Organisational flexibility and competitiveness. New Delhi: Springer India. 
[64] Ouakouak, M. L., \& Ammar, O. (2015). How does strategic flexibility pay off in terms of financial performance? International Journal of Business Performance Management, 16(4), 442-456.

[65] Pauwels, P., \&Matthyssens, P. (2004). Strategic flexibility in export expansion: growing through withdrawal. International Marketing Review, 21, 496-510.

[66] Perez-Valls, M., Cespedes-Lorente, J., \& Moreno-Garcia, J. (2016). Green practices and organisational design as sources of strategic flexibility and performance. Business Strategy and the Environment, 25(8), 529-544. https://doi.org/10.1002/bse.1881.

[67] Price, D. H. R., Beach, R., Muhlemann, A. P., Sharp, J. A., \& Paterson, A. (1998). A system to support the enhancement of strategic flexibility in manufacturing enterprises. European Journal of Operational Research, 109, 362-376.

[68] Rajala, R., Westerlund, M., \& Moller, K. (2012). Strategic flexibility in open innovation: designing business models for open source software. European Journal of Marketing, 46, 1368-1388.

[69] Raynor, M. E., \& Leroux, X. (2004). Strategic flexibility in R\&D. Research Technology Management, 47, 27-32.

[70] Reddy, S. B. (2006). Strategic flexibility and information technology properties: competitive advantage and asset specificity. Journal of Competitiveness Studies, 14, 16-43.

[71] Rindova, V. P., \& Kotha, S. (2001). Continuous 'morphing': competing through dynamic capabilities, form, and function. Academy of Management Journal, 44, 1263- 1280.

[72] Roca-Puig, V., Beltran-Martın, I., Escrig-Tena, A. B., \&BouLlusar, J. C. (2005). Strategic flexibility as a moderator of the relationship between commitment to employees and performance in service firms. International Journal of Human Resource Management, 16, 20752093

[73] Roh, J. J., Yang, M. G., Park, K., \& Hong, P. (2015). Stakeholders' pressure and managerial responses: lessons from hybrid car development and commercialization. International Journal of Business Information Systems, 18, 506-529.

[74] Roy, A. (2016). Strategic flexibility for reconfiguring loan portfolios in Indian banks. Strategic Change- Briefing in Entrepreneurial Finance, 25(5), 525-536.

[75] Rudd, J. M., Greenley, G. E., Beatson, A. T., \& Lings, I. N. (2008). Strategic planning and performance: extending the debate. Journal of Business Research, 61, 99-108.

[76] Saini, A., \& Johnson, J. L. (2005). Organizational capabilities in ecommerce: an empirical investigation of e-brokerage service providers. Journal of the Academy of Marketing Science, 33, 360-375

[77] Sanchez, R. (1995). Strategic flexibility in product competition. Strategic Management Journal, 16, 135-159.

[78] Sanchez, R., \&Heene, A. (1997). Reinventing strategic management: new theory and practice for competence-based competition. European Management Journal, 15, 303-317.

[79] Schulze, M., \& Heidenreich, S. (2017). Linking energy-related strategic flexibility and energy efficiency: The mediating role of management control systems choice. Journal of Cleaner Production, 140(3), 1504-1513.

[80] Sharfman, M. P., \& Dean, J. W. (1997). Flexibility is strategic decision making: informational and ideological perspectives. Journal of Management Studies, 34(2), 191-217.

[81] Shadi, R. (2016). The effect of strategic flexibility and organizational legitimacy on green management performance in companies of Aras free trade zone. IIOAB Journal, 7(2), 84-92.

[82] Shimizu, K., \&Hitt, M. A. (2004). Strategic flexibility: organizational preparedness to reverse ineffective strategic decisions. Academy of Management Review, 18, 44-59.

[83] Singh, D., Oberoi, J. S., \& Ahuja, I. S. (2013). An empirical examination of barriers to strategic flexibility in Indian manufacturing industries using analytical hierarchy process.
International Journal of Technology. Policy and Management, 13, 313-327.

[84] Sushil (2015). Strategic flexibility: the evolving paradigm of strategic management. Global Journal of Flexible Systems Management, 16, $113-114$.

[85] Tamayo-Torres, I., Ruiz-Moreno, A., \&Verdu, A. J. (2010). 'The moderating effect of innovative capacity on the relationship between real options and strategic flexibility. Industrial Marketing Management, 39, 1120-1127.

[86] Tan, J., \& Zeng, Y. (2009). A stage-dependent model of resource utilization, strategic flexibility, and implications for performance over time: empirical evidence from a transitional environment. AsiaPacific Journal of Management, 26, 563-588.

[87] TenDam, H. W. (1987). Managerial flexibility: a strategic asset. Leadership and Organization Development Journal, 8, 11-16.

[88] Verdú-Jover, A. J., \& Gómez-Gras, J.-M. (2009). Measuring the organizational responsiveness through managerial flexibility. Journal of Organizational Change Management, 22(6), 668-690.

[89] Verdú-Jover, A. J., Gómez-Gras, J.-M., \&Lloréns-Montes, F. J. (2008). Exploring managerial flexibility: determinants and performance implications. Industrial Management and Data Systems, 108, 70-86

[90] Wang, T., Libaers, D., \& Jiao, H. (2015). Opening the black box of upper echelons in China: TMT attributes and strategic flexibility. Journal of Product Innovation Management, 32, 685-703.

[91] Wang, X., Qi, Y., \& Zhao, Y. (2018). Individual unlearning, organizational unlearning and strategic flexibility: The down-up change perspective. Baltic journal of management, 14(1), 2-18.

[92] Wei, Z., Yi, Y., \& Guo, H. (2014). Organizational learning ambidexterity, strategic flexibility, and new product development Journal of Product Innovation Management, 31, 832-847.

[93] Worren, N., Moore, K., \& Cardona, P. (2002). Modularity, strategic flexibility, and firm performance: a study of the home appliance industry. Strategic Management Journal, 23, 1123-1140.

[94] Xiu, L., Liang, X., Chen, Z., \& Xu, W. (2017). Strategic flexibility, innovative $\mathrm{HR}$ practices, and firm performance A moderated mediation model. Personnel review, 46(7), 1335-1357.

[95] Xu, C., Wells, E., LeFevre, J. A., \& Imbo, I. (2014). Strategic flexibility in computational estimation for Chinese and Canadianeducated adults. Journal of Experimental Psychology-Learning Memory and Cognition, 40(5), 1481-1497.

[96] Yawson, R. M., \&Greiman, B. C. (2017). Strategic flexibility analysis of agrifood nanotechnology skill needs identification. Technological Forecasting and Social Change, 118, 184-194

[97] Yi, Y., Gu, M., \& Wei, Z. (2017). Bottom-up learning, strategic flexibility and strategic change. Journal of Organizational Change Management, 30(2), 161-183.

[98] Ying, Y., Deng, P., \& Liu, Y. (2016). Strategic flexibility, institutional hardship, and international expansion strategy of Chinese new ventures. China- An International Journal, 14(4), 118-130.

[99] Young-Ybarra, C., \& Wiersema, M. (1999). Strategic flexibility in information technology alliances: the influence of transaction cost economics and social exchange theory. Organization Science, 10, 439-459.

[100] Zahra, S. A., Hayton, J. C., Neubaum, D. O., Dibrell, C., \& Craig, J. (2008). Culture of family commitment and strategic flexibility: the moderating effect of stewardship. Entrepreneurship Theory and Practice, 32, 1035-1054.

[101] Zhang, M. J. (2005). Information systems, strategic flexibility and firm performance: an empirical investigation. Journal of Engineering and Technology Management, 22, 163-184.

[102] Zhou, K. Z., \& Wu, F. (2010). Technological capability, strategic flexibility, and product innovation. Strategic Management Journal, $31,547-561$ 